\title{
Research on the Remedy System in China's Government Procurement Contract Awarding Phase
}

\author{
Fu-Guo Cao', Jiang-Yu Huang ${ }^{2}$ \\ ${ }^{1}$ The School of Law, Central University of Finance and Economics, Beijing, P. R. China \\ ${ }^{2}$ The School of Public Finance and Taxation, Central University of Finance and Economics, Beijing, P. R. China
}

Email address:

1136591236@qq.com (Fu-Guo Cao), hjiangyu@email.cufe.edu.cn (Jiang-Yu Huang)

To cite this article:

Fu-Guo Cao, Jiang-Yu Huang. Research on the Remedy System in China's Government Procurement Contract Awarding Phase. Journal of Investment and Management. Vol. 7, No. 2, 2018, pp. 59-69. doi: 10.11648/j.jim.20180702.13

Received: April 5, 2018; Accepted: April 23, 2018; Published: May 15, 2018

\begin{abstract}
Government procurement regulations require efficient implementation and remedy systems to achieve the goals of public procurement and protect the suppliers' business opportunities. In the phase of awarding public procurement contracts, the establishment of a more independent and professional organization will increase the authority, credibility, and efficiency of dispute resolution in complaint processing. In order to protect the rights and interests of the participants, the public procurement suspension procedures should be further improved; the application of the Alternative Dispute Resolution (ADR) system such as mediation, arbitration, etc, should be encouraged. When a supplier claims damages for losses due to illegal activities, it should use a more diversified dispute resolution mechanism. The remedy system in the awarding phase of public procurement contracts can enable China's public procurement system to better meet the needs of the Government Procurement Agreement (GPA) and enable Chinese companies to participate in international competition fairly and effectively. China should establish professional and independent complaints resolving institutions. Improve the suspension procedures for the dispute settlement in the Public Procurement contract awarding phase.
\end{abstract}

Keywords: Remedy System, Contract, Award Phase, Government Procurement, China

\section{Introduction}

Public procurement involves multiple parties, including government Procurer, procurement agencies, unspecified suppliers, procurement supervision agencies, and the public, which makes the diversity of legal relationships in public procurement and the complexity of the dispute remedy.

The bidding, tendering and reviewing of disputes during the award phase of the government procurement contract, the design of the challenge complaint system, is the key to the sound development of the government procurement system. In any countries (regions). The government is the largest procurement entity, and the competition among suppliers who participate in government procurement is intense fierce. This has led to high frequency of disputes in the procurement's tendering and awarding phases. Prior to the implementation of laws and regulations, such as the "Government Procurement Law" [1], suppliers often have nowhere to seek assistance for public bidding or public law. The establishment of a government procurement challenge-and-complaint mechanism ensure suppliers' remedy and protection. The remedy system is also in line with the Government Procurement Agreement (GPA) requirements for the protection of suppliers' rights, which is significant for opening the procurement market and increasing suppliers' participation [2].

The works, goods, services procured by the government are closely related to the national economy and the people's livelihood [3]. They are complex and have a wide range of impacts. Once a dispute arises, it affects not only the government procurers and the participating suppliers, but also affects the quality and efficiency of the provision of public services by the government. Therefore, the disputes in government procurement need to be solved quickly and effectively, the challenge and complaint mechanism should meet this demand.

During the award phase of public procurement contracts, government procurers, successful bidders, and unsuccessful suppliers are protected by the government procurement 
system. Suppliers are involved in government procurement activities and have the essential characteristics of pursuing maximum benefits. The suppliers and the government procurers are in an equal transaction relationship, and the procurement entities must not infringe on the supplier's rights. Remedy to the damages of suppliers by government procurement will not only minimize the damage of suppliers, but also realize value for money for government procurement effectively.

\section{Two models of the Public Procurement Challenge and Complaint Mechanism}

GPA is a plurilateral agreement which aims to standardize the behavior of members, to promote the openness of government procurement market and to achieve greater liberalization of world trade [4] .

In order to ensure that the GPA rules are implemented, the GPA requires the procuring entity to comply with the procurement rules and correct the irregularities promptly through the supplier's challenge and complaint mechanism.

The GPA clearly requires each member to provide the supplier with "prompt, effective, transparent and non-discriminatory" complaint procedures for domestic disputes, and stipulates challenge and complaints agencies, remedy procedures [5]. The WTO Government Procurement Committee passed the new GPA on March 30, 2012. The changes related to the new GPA remedy system include: First, some changes have been made to the members' domestic challenges and complaints procedures (such as reduce the demand for the independence of the complaints processing institutions, etc.). And the second is to resolve the dispute over the scope of GPA agreement (Article 19, paragraph 7) through arbitration procedures. According to the 1994 and 2012 GPA rules, when it comes to the disputed complaint resolving agencies, members can choose between two models:

Model 1 Single-institution, single-channel model. That is, only the court or an independent administrative review agency is authorized to handle the supplier's challenges and complaints.

Model 2 Multi-agency, multi-channel model. That is, through a number of agencies, multiple channels, through one or more procedures to solve the supplier's challenges and complaints.

Based on the above two models, This paper has summarized the challenge and complaint procedure of the public procurement contract about the typical countries or regions.

Table 1. Two models of Government procurement challenge and complaint procedures.

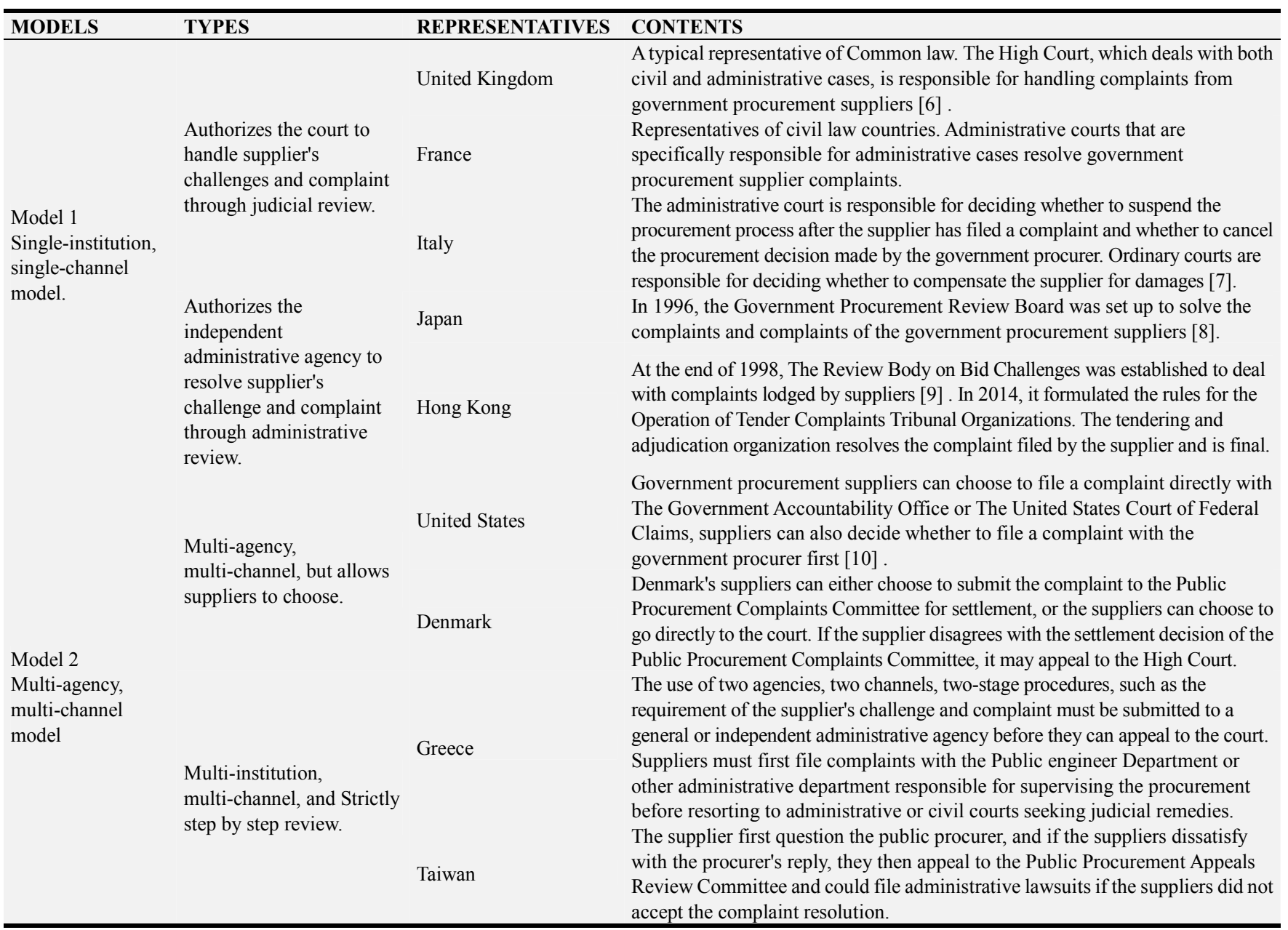




\begin{tabular}{lll}
\hline MODELS & REPRESENTATIVES & CONTENTS \\
\hline & $\begin{array}{l}\text { The primary review body for resolving public procurement supplier complaints } \\
\text { is the procurement office of the Federal Bureau of Competition } \\
\text { (Vergabekammer). If suppliers are not satisfied with the decisions they have } \\
\text { made, they may seek judicial remedies from the procurement court } \\
\text { (Vergabesenat des Oberlandesgerichts) of the Appeal Court. } \\
\text { Complaints caused by domestic government procurement are resolved by the } \\
\text { purchasing unit. If the complainant is dissatisfied with the result, the suppliers } \\
\text { can directly sue in court. } \\
\text { In international bidding, if the bidding company believes that the procurer } \\
\text { entities have violated the government procurement agreement during the } \\
\text { procurement process, the suppliers may first challenge the procurers and seek } \\
\text { solutions through negotiation. }\end{array}$ \\
& $\begin{array}{l}\text { If the two parties fail to reach a consensus, the bidder may file complaint with the } \\
\text { Korean International Contract Disputes Mediation Committee to request an award. }\end{array}$ \\
&
\end{tabular}

The controversy in the award phase of China's government procurement contract is to adopt the "three-institution, three-channel, and three-phase" approach. The public procurement supplier or potential supplier first challenges the procurers or the procurement agencies. If the suppliers are dissatisfied with the answers, they can file a complaint with the financial department at the same level. If the suppliers are still not satisfied with the complaint, they have the right to file an administrative reconsideration or administrative litigation (Articles 10 and 19, Order No. 94 of the Ministry of Finance of China).

In 2007, the OECD used a questionnaire to study the main members of European Union (EU) domestic review and remedy system during the award phase of public procurement contracts [11]. Most EU member states have set up special public procurement review agencies to resolve disputes in the award phase of public procurement contracts [12] .

Table 2. Dispute review agency in the public procurement contract award phase.

\begin{tabular}{llll}
\hline countries & Agency Names & Countries & Agency Names \\
\hline Austria & Federal Public Procurement Offices and regional institutions) & Bulgaria & Commission on the Protection of Competition \\
Cyprus & Tenders Review Authority & Czech Republic & Office for the Protection of Competition \\
Denmark & Complaints Board for Public Procurement & Estonia & Public Procurement Commission \\
Germany & 17 Public Procurement Chambers & Hungary & $\begin{array}{l}\text { Public Procurement Council with its specialised arm, } \\
\text { the Arbitration Committee }\end{array}$ \\
Latvia & Procurement Monitoring Bureau & Malta & Appeals Board of the Department of Contracts \\
Poland & Public Procurement Office (managing the system of arbitrators) & Romania & National Council for Solving Legal Disputes \\
Slovakia & Office of Public Procurement & Slovenia & National Review Commission for the Review of Public \\
& & & Procurement Award Procedures \\
\hline
\end{tabular}

In conclusion, the main characteristics of dispute resolution in the government procurement contract award phase include:

Firstly, In the award phase of the contract, whether directly seeking judicial remedy or administrative remedy, legislators are fully aware of the significance of negotiations between suppliers and procurers, encouraging and prompting suppliers and procurers to resolve disputes on their own [13] .

Secondly, in the selection of specific judicial remedies channels, whether a supplier initiates a civil action or an administrative action, the choice depends on the specific recognition of the nature of government procurement by the legal traditions of different countries [14]. For example, Germany has filed a civil lawsuit [15]. France is categorized as an administrative act and can only lodge an administrative lawsuit [16].

Thirdly, attach importance to adopting a diversified dispute resolution mechanism. In the dispute resolution method of the public procurement contract award phase, challenge or complaint is an alternative remedy. In addition, the supplier may apply for mediation. For example, in Korea, "suppliers may first question the public procurer and seek solutions through negotiation. If the two parties fail to reach a consensus, the bidder may file a complaint with the Korean International Contract Disputes Mediation Committee to request an award".
Suppliers can also directly initiate litigation without complain or challenge at first. For example, in the United States, "a dispute with the procurer's contractor is not a prearrangement for filing an objection to the Federal Audit Office, and the supplier can either choose the procurement officer or the Federal Audit Office to requests administrative review and may also choose to conduct judicial proceedings in the Federal Compensation Court or the Federal District Court ".

Fourthly, in most countries or regions, regardless of the model of review adopted during the award stage of the public procurement contract, a special public procurement review body will be set up to manage the review process and allow relevant experts to participate in public procurement dispute resolution.

\section{Cases Analysis on Dispute Resolution in Awarding Stage of Public Procurement Contract in China}

Supplier's remedy is the essence of public procurement law [17]. In Chapter 6 of the "China Government Procurement Law", China has specifically provided a challenge and complaints mechanism for suppliers in response to the special 
nature of the disputes during the awarding stage of public procurement contract, to ensure the effective operation of the whole government procurement legal system [18].

According to "China Government Procurement Law", the remedy mechanism for the award stage of government procurement contracts mainly includes inquiries (Article 51, China Government Procurement Law), challenge, complaints [19], administrative reconsideration and administrative litigation.

\subsection{The Practice of Government Procurement Challenges and Complaints in China}

Since 2012, the Ministry of Finance has dealt with 1194 cases of various government procurement cases (include reports, complaints, and active supervision and inspection projects). There were 361 complaint cases. Except for historical cases, 18 cases were administrative justice cases and the Ministry of Finance won the cases. The number of complaints handled by the Ministry of Finance as a whole showed an upward trend. According to publicly available information, the complaints involve improper contents of the tender documents, inconsistent bidder qualifications, unsatisfactory bid products, unfair tendencies in bidding activities, other illegal activities of the bid winner, misconduct of the purchaser, and procurement agents.

In order to standardize the unified enforcement judgment standards, reduce the flexibility of law enforcement discretion, correct implementation deviations of laws and regulations, promote the standardization of government procurement law enforcement, and maintain the government procurement market order, the Ministry of Finance issued 10 guiding cases for resolving government procurement challenges and complaints. The category of the cases include 7 complaint cases and 3 report cases, covering the procurement of various types of goods, services, and works.

The dispute includes the procurer's illegal supplier qualifications, illegal agency procurement procedures, score criteria setting does not correspond to quantitative indicators of review factors, suppliers provide false materials for winning bids, malicious collusion, obtaining evidence by illegal means for making complaints, etc. From the results perspective, it includes the establishment of complaints, dismissal of complaints, invalid complaints. The parties are ordered to make rectification, and the suppliers and agencies are given administrative penalties [20]. The Ministry of Finance explores dispute resolution mechanisms in the stage of awarding public procurement contract. In recent years, the awareness of protection rights by the suppliers have been continuously enhanced, and cases of complaints accepted by financial departments at all levels have increased dramatically. In 2016, the cases number of government procurement complaints and reports reached 5,011, which were 1.5 times and 3 times of that in 2015 and 2014, respectively [21].

In order to deal with government procurement complaint cases in an impartial manner, China Ministry of Finance has explored and improved the resolving mechanism for procurement complaints.

First, an additional government procurement management office is set up in the Ministry of Finance to handle and supervise the government procurement complaint procedure, and provide strong supports from the agencies and staff. The Ministry of Finance has set up a special complaint resolving office, a conference room, etc. The complaint procedure must be recorded.

Second, establish and improve the internal control system, and formulate 13 systems such as "Regulations for Handling Complaints within the Office", "Administrative Measures for the Government Procurement Expert Review Committee", "Code of Conduct for Complaints and Reporting Window", and "Confidentiality System", "system administrator", etc.

Third, hire legal counsel to assist in the participation of administrative adjudication. At present, it has hired 3 senior lawyers as consultants and formed 4 working groups, totaling 11 people.

Fourth, introduce the expert review mechanism. In the process of handling complaints, an expert review committee meeting is organized to focus on examination of complaints, and related evidence materials provided by experts used as basis and evidence for making decisions [22].

Fifth, in order to ensure fast and smooth channels for the protection of suppliers' rights, a government procurement complaints reception window has been set up, and public telephone and address information have been disclosed. The "Government Procurement Complaint Window Code of Conduct" was formulated, requiring staffs to respond to stringent specifications [23].

\subsection{Judicial Cases in the Awarding Stage of Public Procurement Contract}

\subsubsection{The Analysis of Judicial Cases in the Challenge and Complaint Procedure}

In order to study the dispute of the awarding stage of government procurement contract, this paper analyze the judicial cases in recent years. Before December 30, 2017, there were 325 public procurement lawsuits triggered by complaints. According to the classification of cases, administrative cases accounted for about $94 \%$, civil cases accounted for about $5 \%$, and criminal cases accounted for about $1 \%$. According to the division of trial courts, the number of cases handled by basic courts accounted for about $49 \%$, the number of cases handled by intermediate courts accounted for about $44 \%$, and the number of cases handled by high courts accounted for about $7 \%$. According to the division of trial procedures, the number of cases in the first instance accounted for about $54 \%$, cases in the second instance accounted for about $44 \%$, and retrial cases accounted for about $2 \%$.

Through studying 325 judicial cases, the court supported a total of 45 cases of suppliers, accounting for approximately $13.85 \%$. For the plaintiffs (suppliers) to sue the financial department or the government departments that have made administrative reconsideration, the results of the judgments made by the court mainly include 7 different situations. (1) Order the financial departments to re-determine the complaints of the plaintiffs (suppliers). (2) Revoke the administrative reconsideration decision made by the 
provincial (city or county) government. (3) Revocation of the "Government Procurement Complaint Processing Decision Statement" made by the defendant's financial department or the tendering authority. (4) A decision of the defendant (Financial department) to make a determination that the facts are not clear. To violate due process and to apply the law wrongly shall be revoked according to law. (5) The defendant who first tried to make the appeal was found unclear in the administrative reconsideration decision, and the request for reconsideration was omitted and should be revoked. (6) The defendant should make a reconsideration decision on the reconsideration application matters of the appellants. (7) The court determined that the administrative reconsideration decision made by the government was illegal and confirmed that the financial department's handling of government procurement complaints was illegal.

The civil cases involved in the public procurement contract award stage include: (1) Damage to business reputation, unfair competition, infringement of commercial secrets, etc. (2) Disputes between successful bidders and government procurer and government procurement agencies. (3) The original successful bidder refused to accept the "reorganization of procurement" and filed a civil lawsuit. (4) The second place winner filed a challenge and complaint against the first successful bidder and requested compensation for the loss of the sample. (5) The unsuccessful suppliers sued the court and demanded the government procurer to compensate for the bidding fees, and the court refused to support it [24].

\subsubsection{Beijing Modern WO ER Economic and Trade Co., Ltd. Sued China Ministry of Finance}

Among the complaints disputes resolved by the Ministry of Finance, the most significant one was the complaints of Beijing Modern WO ER Economic and Trade Co., Ltd. has started its complaints in 2003 and continued into 2017. In September 2003, the State Council of China approved the National Development and Reform Commission and the former Ministry of Health in the preparation of the "Planning for the Construction of Medical Emergency Management System for Public Health Emergencies". According to this requirement, the former Ministry of Health as a government procurer, the commissioned procurement agency, GUOXIN TENDERING, conducted an open tender for the medical treatment system project in October 2004. The tender number is GXTC-0404038. Modern WO ER Economic and Trade Co., Ltd. (hereinafter referred to as Modern WO ER) to participate in the D package of blood gas analyzer of the tender, which is the bid item for which the case was filed.

Table 3. The process of the case of Modern WO ER complaint.

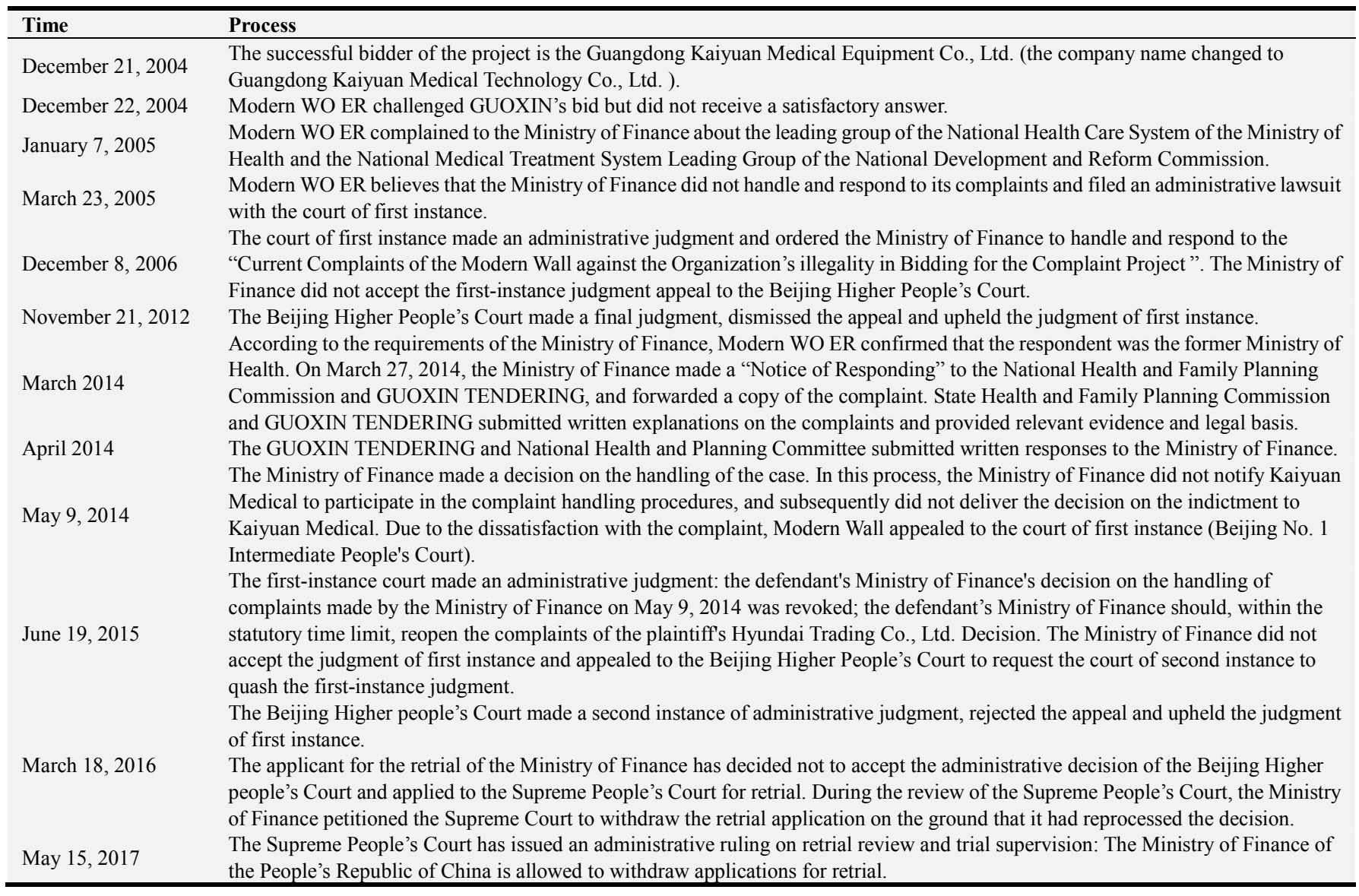

Modern WO ER's challenge and complaint concerning the "National Packages for Medical Treatment System (No. GXTC-0404038) Package D_Blood Gas Analyzer" began on
December 22, 2004, and went to the Supreme Court on May 15,2017 . This case lasted nearly 13 years. Although this case has some certain degree of particularity, it also reflects the 
existence of problems in the remedy system of China's public contract awarding stage.

\subsubsection{The Case of Compensation for Damages in the Awarding Phase of Government Procurement Contract}

In the award phase of the public procurement contract, the damaged supplier may request the government procurement entities and other entities to compensate. According to the "wenshu.court.gov.cn". This paper has summarized the typical cases in which Chinese courts have accepted damages in the awarding phase of government procurement contracts before December 2017.

Table 4. The cases of compensation for damages.

Case Names
Hunan Province Construction Engineering
Group Corporation v. Jiujiang City Forestry
Bureau Bidding Tender Dispute Case
Dalian Xinsheng Fire Engineering Co., Ltd.
and Dalian Aric Electromechanical
Equipment Co., Ltd. appealed for
infringement disputes in bidding.
XX Bidding Center and XX Co., Ltd.
colluded with bid unfair competition dispute
appeal
Jiangxi Kang Ying Medical Technology Co.,
Ltd., Zhanjiang Business exhibition
company, and Guangdong Province, the
second People's Hospital, Guoyi Bidding Co.,
Ltd. collusion in the bidding of unfair
competition disputes retrial civil adjudication

Plaintiff Mei-NaiEr Furniture Co., Ltd. and the defendant Zhongshan construction project management office, Guangdong province electromechanical equipment Tendering Center Co., Ltd. tender and bid for sale contract dispute first Instance civil judgment

The plaintiff Huaihua Hongyu Printing Factory dissatisfied with the defendant Huaihua Finance Bureau procurement tender administrative acts and administrative compensation case

\section{Case Contents}

The liability for the award phase of the public procurement contract shall apply to the provisions of liability for negligence in the conclusion of the contract. The bid evaluation committee's decision to abolish the winning bid is an erroneous interpretation of the administrative regulations and violates the honesty and credit in the contractual contracting process. The losses caused to the bidder shall be borne by the commissioner of the bid evaluation committee (the tenderer)Jiujiang Kelinsuo. The bid bond has the characteristics of deposit, and the bidder shall double return the bid security to the bidder. The tenderer Jiujiang KeLinSuo provided compensation for the direct losses of the plaintiff Hunan Jianzhong. The facts confirmed in the "Complaint resolving Decision" are related to the trial results of the civil lawsuit in this case. However, after Xinsheng Company became aware of the resolving results of the "Complaint Resolution Decision ", it deliberately refused to receive the "Complaint resolving Decision", resulting in the administrative procedures have not yet ended. Therefore, the court of first instance ruled that the lawsuit of Xinsheng Company should be dismissed and that Xinsheng Company should not initiate a civil action after the end of the administrative procedure.

The "Tendering Document" issued by the XX Bidding Center is an offer invitation, not a contract, and colluding unfair competition disputes is a joint infringement complaint. Therefore, the court of first instance has jurisdiction over the case.

Collusion bid unfair competition disputes. The focus is whether the lawsuits of Huanzhou Company and Chen Dongmei meet the admissibility criteria. This case is a dispute of unconscionable bids and is a dispute of infringement. Huanzhou Company and Chen Dongmei submitted preliminary evidence for their claim and should be deemed to have direct interest in the case. Huan Zhou Company and Chen Dongmei filed the lawsuit in accordance with Article 119 of the Civil Procedure Law. Whether Huanzhou Company and Chen Dongmei are qualified for bidding and whether their claims can be supported are issues identified by the entity and the court will not review it at the phase of procedure review.

The perpetrator shall be liable for infringement if he or she has infringed upon the property rights of others by mistake. The defendant Guangdong Electronic mechanical Tendering Co., Ltd. was entrusted by the defendant Zhongshan Office of Construction to organize a bid for the project involved in this case. After receiving the questioning letter from the plaintiff, Mei-Nai Er Company, it did not find that the situation affecting the fairness of the procurement result was promptly corrected. The input losses of the plaintiffs for participating in bidding are irrecoverable, and the defendant should bear the liability for compensation for the plaintiff's losses in bidding. There is no direct causal relationship between the plaintiff's claimed loss of profits and the defendant's actions.

The plaintiff claimed that there was no factual or legal basis for the claim. Therefore, the court did not support the plaintiff's claim. The defendant Huaihua Finance Bureau violated the administrative action of the government procurement bid for the "2017-2018 annual fixed-point printing agreement provision for administrative institutions at Huaihua City level" project.
Regarding the awarding phase of government procurement contract, the main disputes of the damages in the complaint include: collusion bidding improper competition dispute (tort liability), contracting fault liability, civil jurisdiction, administrative compensation in administrative lawsuit, compensation scope, etc.

Summarizing the typical cases in China's government procurement disputes compensation for damages, it can be seen that when a party seeks compensation through a civil lawsuit, it generally receives support from the court if there is sufficient evidence. The scope of compensation includes direct losses and does not include loss of expected benefits. Civil liability shall be allowed to be dealt with through ADR, including conciliation, negotiation and arbitration [25]. However, the use of arbitration must require prior clarification.
If the parties agree to submit the dispute to the arbitration of this Council, the arbitration rules apply. The arbitration agreement refers to the agreement that the parties agree to submit the dispute that has occurred or may occur in the specific legal relationship between them [26]. Arbitration agreements include arbitration clauses in contracts or arbitration agreements concluded in other written forms. The arbitration agreement exists independently and is not affected by the validity of the contract. There must be an arbitration agreement, etc, when applying for arbitration. Therefore, in the government procurement challenge and complaints procedure, the relevant parties can reach an arbitration agreement with the responsible entities, clearly by the specific arbitration body to deal with the dispute between the two parties. 


\section{Analysis of the Remedy Issues in the Awarding Phase of Government Procurement Contract}

\subsection{Poor Remedy Effect of Complaints in the Awarding Phase of Government Procurement Contract}

The characteristics of the government procurement remedy mechanism established in China's "Government Procurement Law" includes: the combination of internal remedies and external remedies, the combination of administrative review and judicial review, the multiplicity of remedy methods and the complexity of procedures, the supplier can file a complaint to the government Procurement supervision only after challenging. Those who are not satisfied with the complaint can conduct administrative reconsideration or administrative litigation. This remedy approach seems complete, but there are many problems in the process of law application.

Whether the challenge and complaint procedures are effective? The "China Government Procurement Law" stipulates the challenge procedure, but the procurer and the procurement agency seldom set up an independent challenge resolve agency, and there not exist specialized institutions to handle the challenge. Most of them are handled by unprofessional staffs.

China has adopted a multi-agency, multi-channel, and step-by-step review model in the award phase of government procurement contracts. According to the provisions of the "Government Procurement Law", "Administrative Procedure Law", and the "Administrative Reconsideration Law", suppliers complained after the challenge and then filed a lawsuit with the court [27]. The processing time was too long. Judging from the judicial review, the remedy sought by supplier does not resolve disputes quickly and effectively, which do not meet the requirements of government procurement.

The supplier is not satisfied with the complaint resolution and whether it is effective to sue the court. When a supplier complains to the financial department, its purpose is to request the financial department to rectify the illegal behavior of the procurement organization. When the supplier is not satisfied with the handling of the complaint, the remedy from the "Government Procurement Law" in China to the supplier points to an administrative reconsideration or administrative litigation.

According to judicial practice, the vast majority of suppliers cannot obtain effective remedies through judicial channels, and judicial trials do not involve disputes between public procurers (or procurement agencies) and suppliers, but rather the supervision of financial departments or government. Whether the administrative reconsideration or administrative litigation with the financial department as the defendant can achieve effective remedy to suppliers [28]?

The practice of public procurement and judicial cases show that the implementation of public procurement law in China is not satisfactory, which has a great relationship with the limitation of efficiency and effective of the remedy system established by our current public procurement law [29] .

If the challenge and complaints case have gone through all the legal procedures, and exhausted all the remedies procedures, the suppliers still have no confidence in a public procurement decision, then the efficiency and effectiveness of such a remedy system is questionable [30]. Theoretically, once the suppliers enter the complaint procedure, this procedure may continue between the government and the court, and the dispute focus of the complaint is far from the public procurement decision itself. In other words, this procedure is of no value to the solution of the suppliers.

\subsection{Government Procurement Resolving Complaints' Institutions Lack of Professionalism, Neutrality}

According to China's government procurement challenge and complaints, suppliers' challenge at this phase play a minor role, most suppliers will complain about the response. It is difficult for government procurement to play an error-correcting function, and it is no doubt that the front procedure of complaint is an obstacle to error-correcting procedure. This not only reduces the efficiency of government procurement, but also increases the cost of suppliers. The number of successful complaints is generally lower than the number of rejections, the success rate of complaints is relatively low.

The institutions that deal with complaints in China are financial departments at all levels. Government procurement is complex and requires high technical and professional requirements. If it is not handled by a professional and specialized agency, it is more difficult to handle this issue through complaints to "quench" the dispute. This is also the reason why many complaint suppliers will still choose court litigation after filing the complaints.

China's complaint handling agencies are lacking in professionalism. Financial departments are involved in the procurement process and supervision, and their dispute resolving is not neutral. In the face of the increasing number of complaints, our government procurement disputes can not be handled well. This issue has gradually received the attention from Ministry of Finance of China, the supervisors emphasized the importance of perfecting complaints in government procurement, and required the supervisors to study and solve the problems in the construction of government procurement complaints specialization mechanism, and proposed to strengthen the design of government procurement administrative adjudication mechanism. In the handling of public procurement complaints, the financial department should maintain its neutral position as the arbiter [31].

\subsection{The Issues of Suspension Procedures in the Awarding Phase of Government Procurement Contracts}

The characteristics of suspension provisions in current public procurement legislation in China mainly includes:

First, China does not adopt automatic and semi-automatic suspension methods. Instead, it requires the reviewing agency 
to decide whether to suspend the procurement procedure on a case-by-case basis.

Second, although the financial department was authorized to decide to suspend, there is no clear condition for the suspension. The maximum period of suspension is 30 days.

The main problems of such a procurement suspension includes three aspects. (1) It is impossible to suspend the procurement process when dealing with all complaints against government procurement activities. (2) In the multi-level supplier complaint Review Mechanism, the procurement process is likely to be suspended only during the administrative review phase. (3)There is no clear suspension standards. The possibility of a suspension of the procurement procedure mainly depends on the discretionary capacity of the financial sector.

In this lengthy multi-level supplier complaints review mechanism, the "Government Procurement Law" only expressly provides that the financial department may suspend the procurement process during the processing of complaints. At other phases of supplier complaint, the procurement procedure can continue. As a result, without final settlement of the dispute, the procurement contract was signed or even fulfilled.

Based on the existence of the above problems, in practice, it is not uncommon for complaints to have been resolved but the contract has been fulfilled. This has seriously damaged the effectiveness of China's supplier remedy mechanism. On the one hand, Due to the lack of suspension procedures, suppliers cannot obtain business opportunities to participate in procurement competitions even if they win. This will hurt the supplier's complaint review mechanism and even affect the market's confidence in the entire procurement system. On the other hand, the illegal procurement contract can still be signed and performed, which may cause the illegal procurement entities or transaction suppliers to continue to violate the rules in the future procurement activities. This will undoubtedly affect the implementation of government procurement rules, government procurement policy objectives, and the healthy development of the government procurement system.

\section{Improvement Suggestions for Remedy System in the Awarding Phase of Government Procurement Contract}

\subsection{Alternative Dispute Resolution in the Awarding Phase of Public Procurement Contract}

The complete legal logic of regulating the awarding procedure of public procurement contract in China: good government procurement operation Mechanism-improve the use efficiency of government procurement funds-obtain the most reasonable market purchase price-introduce sufficient market competition-give the purchaser a mandatory competitive obligation and supplier fair competition rights-a fast and effective right remedy mechanism. One important approach of remedies is to construct the Alternative Dispute
Resolution (ADR) mechanism in china's public procurement contract awarding phase [32] .

When suppliers seek compensation for damage caused by others' illegal activities, in addition to the lawsuit (Article 79, "Government Procurement Law"), the suppliers may protect their rights through ADR methods such as consultation, mediation and arbitration, etc [33]. In 2016, the Supreme People's Court of China issued the "Opinions on further deepening the reform of pluralistic dispute resolution mechanism in the People's Court", special attention was paid to mediation. And the term "mediation" appeared 156 times. When the supplier adopts litigation remedies, the court may initiate a mediation system. Court mediation can take place before, during, and after the trial. China should encourage the application of various forms of ADR approach in public procurement remedy [34]. Specialized and professional dispute-resolving institutions can participate in the entire process of public procurement, provide remedy to suppliers and other entities, and avoid bad impact caused by the unsolved disputes on the procedure of public procurement [35]. ADR mechanism will have a positive impact on the efficiency of disputes resolution in the awarding phase of government procurement contracts.

\subsection{China Should Establish Professional and Independent Complaints Resolving Institutions}

The exploration made by the Ministry of Finance of the People's Republic of China in the government procurement complaint handling mechanism reflects its emphasis on complaints. However, from the perspective of practical development, China should pay attention to the public procurement complaints handling mechanism at all levels of the country. An independent and professional complaint handling agency should be established to improve the effectiveness of dispute resolution.

The value of an professional-neutral remedy system is that it can resolve disputes and protect the business opportunities and interests of suppliers involved in procurement quickly and effectively.

Any mechanism that may promote the objectivity and specialization of the complaint mechanism can be considered and designed under the existing legal framework, including the establishment of an independent and professional complaints handling committee, and the operation of this committee should have a category of "arbitration mechanism" [36]. China should improve the function of the remedy system in public procurement, other than the overall reform of the legal system.

From the perspective of improving the remedy system, it is feasible and necessary for independent and authoritative government procurement institutions to specifically handle suppliers' complaints [37]. This professional body should follow the principles of non-discrimination, timeliness, transparency and effectiveness, and allow it to take quick and temporary measures, if necessary, to suspend the procurement process. The authority institutions that have been challenged should have the right to correct the illegal decisions of the 
procurement entities, in order to maintain the suppliers' business opportunities or require the procurement agency to compensate the supplier for losses.

Independent complaint handling agencies should allow the public to participate in and improve the finality of the processing results. The institution should pay attention to the dispute resolution of the entire public procurement process, and improve the efficiency and credibility of dispute resolution. More experts are encouraged to introduce to take part in challenge and complain procedure. Professional or technical disputes involved in public procurement projects can be resolved through expert adjudication, and increase the effect of result.

In addition to improving the efficiency of the independent procurement decision-making agency, it is more important to uphold the legitimacy of the institution's resolving procedures. That is, when handling complaints, it is necessary to concern the opinions of the parties and must give them the right to state their opinions and submit evidence. To avoid the possibility of infringement of the legitimate rights and the stakeholders in the absence of corresponding procedural guarantees.

\subsection{Improvement Suggestions of Suspension Procedure in the Awarding Phase of Government Procurement Contract}

The suspension of public procurement is of great significance in the public procurement remedy system. There are two kind of the dispute suspension systems in the award phase of the public procurement contract.

First, apply uniform rules in public procurement to resolve all complaints involving procurement activities. Use a suspension of procurement process in complaints against any government procurement activities.

Second, when the supplier seeks external remedies-resort to administrative review or judicial review - the "semi-automated suspension" approach recommended by the "United Nations Commission on International Trade Law Public Procurement Model Law" is adopted. The procurement process is suspended for seven days before the review agency decides whether to extend the suspension period according to the complaint supplier's request.

Automatic suspension methods are not suitable to recommend to adopt or apply during the challenge phase. Automatic suspension can cause excessive interference with the procurement process. In order to strike a balance between the protection of the suppliers and the avoidance of the excessive interference with the procurement process, the semi-automatic suspension recommended by the Model Law that can be adopted in china [38]. China clarifies specific application conditions based on the actual situation.

\section{Conclusion}

Government procurement remedy mechanisms are conducive to achieving good governance [39]. The remedy system in the awarding phase of public procurement contract can better guarantee the realization of the value goals. Such as the fairness and efficiency of public procurement, promote the professionalism and efficiency of public procurement dispute Resolution in China, facilitate the reform of government procurement, transform government functions, improve the supply of public services and the timely resolving of disputes over public procurement activities, and reduce the unnecessary damage. Efficient remedy system can also avoid the confrontation between the traditional dispute settlement mechanism, which is beneficial to the government and suppliers to maintain a benign relationship. It is in the interests of the Government procurement entities and the suppliers. For the governments, it can enable civil servants to focus on their day-to-day work rather than in protracted litigation battles. The introduction of ADR into the field of public procurement is fundamentally consistent with the goal of quick and effective dispute settlement system. China should deepen the reform of government procurement under the principle of openness, transparency, prompt, effective and fair competition, etc.

\section{List of Abbreviations}

GPA-Government Procurement Agreement, ADR Alternative Dispute Resolution, EU-European Union.

\section{Availability of Data and Material}

All necessary data are within the manuscript.

\section{Conflict of Interest}

There is no conflict of interest.

\section{Acknowledgements}

This paper is based on a research project financially supported by the National Social Science Foundation of China entitled "Research on Public-Private Partnership Legislation" (Grant number: 15ZDB174) and financially supported by "Central University of Finance and Economics Graduate Research Innovation Fund".

\section{References}

[1] Cao G, Zhou F. (2017). Internationalization of Public Procurement Law and Relevance of International Norms and Frameworks: the Case of China. Internationalization of Government Procurement Regulation, 14.

[2] Gian Luigi Albano, Berardino Cesi, Alberto Iozzi. (2017). Public procurement with unverifiable quality: The case for discriminatory competitive procedures. Journal of Public Economics, 45.

[3] Cao G, Zhou F. (2014). Towards Sustainable Public Procurement in China: Policy and Regulatory Framework, Currents Developments and The Case For a Consolidated Green Public Procurement Code. Journal of Malasian and Comparative Law, 15. 
[4] Zhang Xinglin. (2016). The Provisions on Domestic Review Procedures in the WTO Agreement on Government Procurement. Social Sciences in Chinese Higher Education Institutions, (03), 96-108.

[5] Zhang Xinglin. (2013). Research on challenges and Complaints of Government Procurement-GPA Regulations and Selection of Members. Journal of Dongbei University of Finance and Economics, No. 4, 85 .

[6] Pachnou, D. (2003). Bidder Remedies to Enforce the EC Procurement Rules in England and Wales. Public Procurement Law Review, (1), 35-64.

[7] Bovis, C. (2006). EC Public Procurement: Case Law and Regulation. Oxford University Press, 493-499.

[8] Grier, J. H. (2001). Uncertain Prospects for Japan's Bid Challenge Mechanism. Public Procurement Law Review, (3), 81 .

[9] Gao, H. (2007). The Bid Challenge Procedures under the WTO Government Procurement Agreement: A Critical Study of the HongKong Experience. Public Procurement Law Review, (4), 211.

[10] Metzger, R. S., Lyons, D. A. (2007). A Critical Reassessment of the GAO Bid-Protest Mechanism. Wisconsin Law Review,(6), 1225-1269.

[11] OECD.(2007). Public Procurement Review and Remedies Systems in the European Union. SIGMA Papers, No. 41, OECD Publishing, Paris.

[12] Tim Torvatn, Luitzen de Boer. (2017). Public procurement reform in the EU: start of a new era?. IMP Journal, 11(3).

[13] Lian Kiang Tan, Shao Hung Goh. (2017). A Price Review Framework for Maintenance, Repair and Operations Procurement Contracts in the Public Sector. Springer International Publishing.

[14] Nishatabbas Rehmatulla, Tristan Smith, Laurienne Tibbles. (2017). The relationship between EU's public procurement policies and energy efficiency of ferries in the EU. Marine Policy, 75.

[15] Andreas Herbert Glas, Michael Eßig. (2018). Factors that influence the success of small and medium-sized suppliers in public procurement: evidence from a centralized agency in Germany. Supply Chain Management: An International Journal, 23(1).

[16] Olivier Mamavi, Olivier Meier, Romain Zerbib. (2017). How do strategic networks influence awarding contract?. Evidence from French public procurement. International Journal of Public Sector Management, 30(4).

[17] Luo Changfa. (1999). Analysis of the Government Procurement Law and the Government Procurement Agreement. Yuanzhao Publishing Company, 325.

[18] C. f. William E. Kovacic. (1995). Procurement Reform and the Choice of Forum in Bid Protest Disputes, Administrative Law Journal of the American University.

[19] CAO FuGUO, GUO FENG. (2018). Controls and litigation of public contracts in China, in Oversight and Chanllenges of public contracts. Bruylant, 317-326.

[20] The person in charge of the Treasury Department of the Ministry of Finance answered the reporter's question on issuing guidance cases for government procurement, retrieved January 7, 2018 from http://gks.mof.gov.cn/redianzhuanti/zhengfucaigouguanli/201711/ t20171128 2761635.html.

[21] Liu Wei. Speech at the National Government Procurement Working Conference, retrieved December 26, 2017 from http://www.ccgp.gov.cn/news/201712/t20171218_9350010.htm.

[22] Jianjun YU, Xiaofei CAI. (2017). A Decision-Making Model for Supplier Selection in Public Procurement. Management Science and Engineering, 11(1).

[23] Rong Sumei. Obtaining the "Zhenjing" and returning-The leaders of the Department of Finance of Henan Province went to the Ministry of Finance to discuss the improvement of complaint resolving management, China Government Procurement News Network, retrieved January 7, 2018 from http://www.cgpnews.cn/articles/40986.

[24] Cao G. (2013). Building up SME Programmes in Government Procurement in China: Legal Structure, recent developments and the way forward towards the WTO-GPA. Public Procurement Law Review, 22:211-224.

[25] Chia Kuang Lee, Tak Wing Yiu, Sai On Cheung. (2018). Understanding Intention to Use Alternative Dispute Resolution in Construction Projects: Framework Based on Technology Acceptance Model. Journal of Legal Affairs and Dispute Resolution in Engineering and Construction, 10(1).

[26] Sogand Hasanzadeh, Behzad Esmaeili, Samaneh Nasrollahi, Ghada M. Gad, Douglas D. Gransberg. (2018). Impact of Owners' Early Decisions on Project Performance and Dispute Occurrence in Public Highway Projects. Journal of Legal Affairs and Dispute Resolution in Engineering and Construction, 10(2).

[27] Antonio Estache, Renaud Foucart. (2017). The scope and limits of accounting and judicial courts intervention in inefficient public procurement. Journal of Public Economics.

[28] Wang Zhouhuan.(2011). How to Perfect the Remedy System of China's Government Procurement - An Analysis and Consideration of a Case of Government Procurement, edited by Cao Fuguo. Comments on the Public Procurement Law (Volume One). Economic Science Press, 276.

[29] Yang Ran. (2016). Research on the Internationalization of China's Government Procurement Legal System. University of International Business and Economics.

[30] Chao Wang. (2016). Selective Adaptation of International Procurement Rules in the Local Context: Implications for Reforming China's Bid Challenge Procedures. The Chinese Journal of Comparative Law, 4(1).

[31] Chia Kuang Lee, Tak Wing Yiu, Sai On Cheung. (2016). Selection and use of Alternative Dispute Resolution (ADR) in construction projects-Past and future research. International Journal of Project Management, 34(3).

[32] Pui-Lam Ng, Audrius Banaitis. (2017). Construction mediation and its hybridization: the case of the Hong Kong construction industry. Organization, Technology and Management in Construction: an International Journal, 9(1).

[33] Chia Kuang Lee, Tak Wing Yiu, Sai On Cheung. (2018). Understanding Intention to Use Alternative Dispute Resolution in Construction Projects: Framework Based on Technology Acceptance Model [J]. Journal of Legal Affairs and Dispute Resolution in Engineering and Construction, 10(1). 
[34] Natalia Yaskova, Larisa Zaitseva. (2017). Application of alternative dispute resolution in the field of construction projects. IOP Conference Series: Earth and Environmental Science, 90(1).

[35] Bruno Deffains, Dominique Demougin, Claudine Desrieux. (2017). Choosing ADR or litigation. International Review of Law \& Economics, 49.

[36] Cao Fuguo. (2011). Reflections on the Rule of Law of Chinese public procurement under the trillion-yuan domestic demand stimulus plan, edited by Cao Fuguo. Comments on the Public Procurement Law (Volume 1). Economic Science Press, 13-14.
[37] Zhu Zhongyi. (2018). On the Nature of the Challenge and Complaints mechanism and Its Impact on Procedures. China Government Procurement, (03), 13-17.

[38] Zhang Xinglin. (2011). Research on Suspended Remedy Methods in the Supplier Remedy Mechanism, edited by Cao Fuguo. Comments on Public Procurement Law (Volume 1), Economic Science Press, 270.

[39] Cao G. (2009). China's government procurement policy and institutional framework, Francis and Taylor Group, Ed. 